\title{
Titanium Dioxide Recovery from Ilmenite Contained in Ferrotitaniferous Sands from Mompiche-Ecuador
}

\author{
Daniel Trujillo and Lucía Manangón \\ Faculty of Chemical Engineering and Agro-industry, Department of Extractive Metallurgy, Escuela Politécnica Nacional, Quito EC \\ 17012759, Ecuador
}

\begin{abstract}
Titanium dioxide $\left(\mathrm{TiO}_{2}\right)$ was recovered from ilmenite $\left(\mathrm{FeO} \cdot \mathrm{TiO}_{2}\right)$ contained in ferrotitaniferous sands of Mompiche area, by the combination of the thermal treatments of oxidation and carbothermic reduction and the subsequent leaching with hydrochloric acid $(\mathrm{HCl})$ of the thermally treated samples. This study was developed because of the large source of $\mathrm{TiO}_{2}$ that Ecuador has, but has not developed enough research to place an industry to produce this compound. The oxidation at $900{ }^{\circ} \mathrm{C}$ for $3 \mathrm{~h}$ yielded a content of $11 \%$ of $\mathrm{TiO}_{2}$, and the highest oxidation of ilmenite (82\%) was achieved at $1,000{ }^{\circ} \mathrm{C}$ for $1 \mathrm{~h}$. The carbothermic reduction with $15 \mathrm{wt} \%$ carbon at $950{ }^{\circ} \mathrm{C}$ for $2 \mathrm{~h}$ achieved a content of $6 \% \mathrm{TiO}_{2}$ and $21 \%$ ilmenite. The combination of thermal treatments did not increase the content of $\mathrm{TiO}_{2}$ but allowed to obtain more soluble minerals in $\mathrm{HCl}$. The best results of leaching were obtained with $100 \mathrm{~mL}$ of $256 \mathrm{~g} / \mathrm{L} \mathrm{HCl}$ for 6 $\mathrm{h}$ at $70{ }^{\circ} \mathrm{C}$ and $10 \%$ solids of the sample oxidized at $900{ }^{\circ} \mathrm{C}$ for $3 \mathrm{~h}$ and subsequently reduced with $15 \mathrm{wt} \%$ carbon at $950{ }^{\circ} \mathrm{C}$ for $2 \mathrm{~h}$. The optimum leaching time was $4 \mathrm{~h}$, giving a $\mathrm{TiO}_{2}$ of $90 \%$ purity with a recovery of $43 \%$.
\end{abstract}

Key words: Ferrotitaniferous sands, titanium dioxide, carbothermic reduction, acid leaching, ilmenite.

\section{Introduction}

On the north coast of Ecuador, mainly in Mompiche, Esmeraldas, there are potential ferrotitaniferous sands deposits with high contents of $\mathrm{Fe}$ and $\mathrm{Ti}$, as was demonstrated by Diaz [1], who conducted geological and geophysical characterization of the Mompiche area, as well as, Chuquirima and Cortez [2] and Empresa Nacional Minera [3], who used the ferrotitaniferous sands to recover metallic iron. Ilmenite $\left(\mathrm{FeO} \cdot \mathrm{TiO}_{2}\right)$ contained in ferrotitaniferous sands is one of the major sources of titanium dioxide $\left(\mathrm{TiO}_{2}\right)$ which is widely used as a white pigment in paints, cosmetics, coatings, plastics, rubbers, fibers, paper whitening, food additive, suncreen and also it is a source of titanium [4-6].

The $\mathrm{TiO}_{2}$ recovery involves the conversion of ilmenite to $\mathrm{TiO}_{2}$ by oxidation-reduction treatments and the removal of the iron minerals through acid leaching [7]. Due to the high chemical stability of ilmenite, $\mathrm{TiO}_{2}$ extraction requires complicated processes that have not

Corresponding author: Lucía Eliana Manangón, assistant professor, research fields: extractive metallurgy, heterogeneous catalysis and surface science. been studied enough in Ecuador.

$\mathrm{TiO}_{2}$ can be obtained through hydrometallurgy, by leaching with sulfuric acid $\left(\mathrm{H}_{2} \mathrm{SO}_{4}\right)$ or hydrochloric acid $(\mathrm{HCl})$. About $50 \%$ of the $\mathrm{TiO}_{2}$ world production and more than $90 \%$ of the $\mathrm{TiO}_{2}$ production in China are obtained using $\mathrm{H}_{2} \mathrm{SO}_{4}$ as leaching agent. However, this process requires large amounts of concentrated $\mathrm{H}_{2} \mathrm{SO}_{4}$, high temperature and generates a lot of waste, so leaching with $\mathrm{HCl}$ is increasing as an alternative technique [8]. Eqs. (1) and (2) simplified the leaching mechanism of ilmenite into $\mathrm{H}_{2} \mathrm{SO}_{4}$ and $\mathrm{HCl}$ respectively [8, 9].

$\mathrm{FeO} \cdot \mathrm{TiO}_{2}+2 \mathrm{H}_{2} \mathrm{SO}_{4} \rightarrow \mathrm{TiOSO}_{4}+\mathrm{FeSO}_{4}+\mathrm{H}_{2} \mathrm{O}(1)$
$\mathrm{FeO} \cdot \mathrm{TiO}_{2}+4 \mathrm{HCl} \rightarrow \mathrm{TiOCl}_{2}+\mathrm{FeCl}_{2}+2 \mathrm{H}_{2} \mathrm{O}(2)$

With the both acids the predominant leaching mechanism is the unreacted core model, which controlling steps are given by the chemical reaction or the diffusion of the leaching agent to reaction surface, depending on the leaching conditions [7, 8].

When ilmenite is pre-treated by oxidation and carbothermic reduction, leaching in acids is enhanced [7]. The oxidation breaks the strong bond between iron 
oxides and titanium oxides inside ilmenite by oxidation of ferrous oxide (FeO) to ferric oxide $\left(\mathrm{Fe}_{2} \mathrm{O}_{3}\right)$ producing $\mathrm{TiO}_{2}$ and $\mathrm{Fe}_{2} \mathrm{O}_{3}$, if it is oxidized around $800{ }^{\circ} \mathrm{C}$ as shown in Eq. (3), when temperature arrives to $950{ }^{\circ} \mathrm{C}$ pseudobrookite $\left(\mathrm{Fe}_{2} \mathrm{O}_{3} \cdot \mathrm{TiO}_{2}\right)$ is formed according to Eq. (4); the mechanism followed is the unreacted shrinking core model [10].

$$
\begin{gathered}
2 \mathrm{FeO} \cdot \mathrm{TiO}_{2}+1 / 2 \mathrm{O}_{2} \rightarrow \mathrm{Fe}_{2} \mathrm{O}_{3}+2 \mathrm{TiO}_{2} \\
2 \mathrm{FeO} \cdot \mathrm{TiO}_{2}+1 / 2 \mathrm{O}_{2} \rightarrow \mathrm{Fe}_{2} \mathrm{O}_{3} \cdot \mathrm{TiO}_{2}+\mathrm{TiO}_{2}
\end{gathered}
$$

Moreover, carbothermic reduction between 860 and $1,000{ }^{\circ} \mathrm{C}$ provides surface porosity to the mineral, produces more $\mathrm{TiO}_{2}$ and reduces the iron oxide to more soluble species or to metallic iron, according to Eq. (5), converting almost whole ilmenite to $\mathrm{TiO}_{2}[11,12]$.

$$
\mathrm{FeO} \cdot \mathrm{TiO}_{2}+\mathrm{C} \rightarrow \mathrm{Fe}+\mathrm{TiO}_{2}+\mathrm{CO}(\mathrm{g})
$$

If carbothermic reduction is carried out above $1,000{ }^{\circ} \mathrm{C}$, Boudouard reaction is produced as shown in Eq. (6), which is benefit to increase the ilmenite reduction according to Eq. (7) $[11,12]$.

$$
\mathrm{C}+\mathrm{CO}_{2}(\mathrm{~g}) \rightarrow 2 \mathrm{CO}(\mathrm{g})
$$

$$
\mathrm{FeO} \cdot \mathrm{TiO}_{2}+\mathrm{CO}(\mathrm{g}) \rightarrow \mathrm{Fe}+\mathrm{TiO}_{2}+\mathrm{CO}_{2}(\mathrm{~g})
$$

Finally, the iron impurities of pre-treated ferrotitaniferous sands must be removed by acid leaching, which depends on: temperature, acid concentration, particle size, leaching time and stirring speed $[8,9]$.

Due to almost all $\mathrm{TiO}_{2}$ that Ecuador consumes is imported, according to the statistics from Banco Central del Ecuador, it is important to increase the investigation to recover $\mathrm{TiO}_{2}$ from natural sources of this country. Current statistics show that Ecuador imported $795.40 \mathrm{t}$ of $\mathrm{TiO}_{2}$ with a total cost of US\$1,992,350 (2015) [13]. This shows the great interest in this product and makes it imperative to develop a process to recover $\mathrm{TiO}_{2}$ from Ecuadorian ores, which is precisely the aim of this study.

\section{Experiment}

\subsection{Characterization of the Ferrotitaniferous Sands}

Ferrotitaniferous sands collected from Playa del
Suspiro in Mompiche area, Esmeraldas, Ecuador, were physically, chemically and mineralogically characterized. Physical characterization included: determination of bulk density, particle density and particle size $\left(d_{80}\right)$. Chemical characterization was performed by XRF (X-ray fluorescence) in a Thermo Scientific Niton XL3t equipment. Mineralogical composition was determined by XRD (X-ray diffraction) in a Bruker AXS D8 Advance equipment, by semiquantitative analysis of crystalline phases.

\subsection{Oxidation and Carbothermic Reduction of Ferrotitaniferous Sands}

Thermal treatments were performed in a tube furnace Nabertherm P330, RT50-250/11, whose maximum temperature is $1,100{ }^{\circ} \mathrm{C}$, and refractory combustion boats of $10 \mathrm{~g}$ capacity (for the ferrotitaniferous sands of this study) were used.

The oxidative treatment was performed in four steps, in order to analyze the influence of temperature, airflow, particle size and oxidation time on the decomposition of ilmenite and the subsequent conversion to $\mathrm{TiO}_{2}$.

To analyze the effect of temperature during oxidation, experiments were performed with an airflow of $510 \mathrm{NL} / \mathrm{h}$ for $3 \mathrm{~h}$ at $650,700,750,800,900,950$ and $1,000{ }^{\circ} \mathrm{C}$. Besides, experiments without airflow were executed and compared with the previous experiments. The effect of particle size was studied using the ferrotitaniferous sands pulverized to a particle size of $75 \mu \mathrm{m}\left(d_{100}=75 \mu \mathrm{m}\right)$. To analyze the effect of oxidation time, 1,2 and $3 \mathrm{~h}$ of oxidation were tested.

The carbothermic reduction was carried out with powdered activated carbon (80.2\% fixed carbon) as the reductant, and the influence of the percentage of carbon, temperature, reduction time and the gaseous atmosphere were analyzed on the decomposition of ilmenite and their subsequent conversion to $\mathrm{TiO}_{2}$.

The influence of the percentage of carbon was evaluated at $1,050{ }^{\circ} \mathrm{C}$ for $1 \mathrm{~h}$ with $10,15,20$ and $40 \mathrm{wt} \%$ of carbon. The effect of temperature was 
studied at 900,950 and $1,050{ }^{\circ} \mathrm{C}$. To analyze the influence of reduction time, essays were performed for 1 and 2 h. Besides, the effect of inert gaseous atmosphere with $400 \mathrm{NL} / \mathrm{h}$ of carbon dioxide $\left(\mathrm{CO}_{2}\right)$ was evaluated.

To study the combination of the thermal treatments, essays were performed by combining the results that showed the lowest content of ilmenite or the highest percentage of $\mathrm{TiO}_{2}$, obtained from the oxidation step, with the best results from the carbothermic reduction.

\subsection{Hydrochloric Acid Leaching of Oxidized-Reduced Ferrotitaniferous Sands}

Iron oxides and other impurities found in the thermally treated ferrotitaniferous sands were separated from $\mathrm{TiO}_{2}$, which is slightly soluble in $\mathrm{HCl}$, by leaching in $256 \mathrm{~g} / \mathrm{L} \mathrm{HCl}$. Leaching essays were performed inside a fume hood over a heating plate at $70{ }^{\circ} \mathrm{C}$ with magnetic stirring.

Leaching process was studied by varying the pulp density (5, 10 and 20\%) and leaching time (1, 2, 3, 4, 5 and $6 \mathrm{~h}$ ). Additionally, the leaching of only reduced ferrotitaniferous sands was performed to evaluate the influence of pre-oxidation on the leaching efficiencies. The solid product obtained was washed with distilled water, dried at $100^{\circ} \mathrm{C}$ for $5 \mathrm{~h}$, calcined at $800{ }^{\circ} \mathrm{C}$ for $2 \mathrm{~h}$ and analyzed by XRD and XRF.

The leachates were analyzed by atomic absorption spectrophotometry (AA) in a Perkin Elmer Analyst 300 equipment to determine the concentrations of $\mathrm{Fe}$ and $\mathrm{Ti}$. XRD analysis determined the purity of $\mathrm{TiO}_{2}$. XRF analyses together with AA analyses were used for metallurgical balances.

\section{Results}

The studied ferrotitaniferous sands have a bulk density of $3.0 \mathrm{~g} / \mathrm{cm}^{3}$ and a particle density of $4.9 \mathrm{~g} / \mathrm{cm}^{3}$, demonstrating the presence of dense minerals, which is characteristic of ferrotitaniferous sands and agrees with the densities of the minerals that compose these sands, such as ilmenite $\left(4.70 \mathrm{~g} / \mathrm{cm}^{3}\right)$, magnetite $\left(5.18 \mathrm{~g} / \mathrm{cm}^{3}\right)$ and hematite $\left(5.26 \mathrm{~g} / \mathrm{cm}^{3}\right)$ [14]. The particle size $\left(d_{80}\right)$ is $177 \mu \mathrm{m}$ and corresponds to fine particles, so comminution was not necessary to prepare the samples for subsequent essays.

The chemical analysis shown in Table 1 indicates the ferrotitaniferous sands have a content of $\mathrm{Fe}$ and $\mathrm{Ti}$ of 52.1 and $15.4 \%$, respectively.

The semiquantitative mineralogical analysis (XRD) showed the ferrotitaniferous sands contain 56\% ilmenite, $25 \%$ hematite, $12 \%$ magnetite and $7 \%$ cummingtonite, the latter is a mineral that contains in its structure the impurities found in the chemical analysis.

\subsection{Thermal Oxidative Treatment}

Fig. 1 shows that between 650 and $750{ }^{\circ} \mathrm{C}$, the percentage of ilmenite almost did not change, and the ferrotitaniferous sands were not altered; only a small amount of $\mathrm{TiO}_{2}$ appeared. Hematite suffered changes from baseline and increased to a maximum of $42 \%$ at $900{ }^{\circ} \mathrm{C}$, while at $950{ }^{\circ} \mathrm{C}$ and $1,000{ }^{\circ} \mathrm{C}$ decreased dramatically and reached a content of $21 \%$. The pseudobrookite showed a drastic increase at 950 and $1,000{ }^{\circ} \mathrm{C}$, reaching a maximum of $54 \%$. Between 750 and $1,000{ }^{\circ} \mathrm{C}$ the percentage of ilmenite decreased while temperature increased, and a minimum ilmenite content of $9 \%$ at $1,000{ }^{\circ} \mathrm{C}$ was reached. The percentage of $\mathrm{TiO}_{2}$ increased at higher temperatures, reaching a peak of $11 \%$ at $900{ }^{\circ} \mathrm{C}$, while between 950 and $1,000{ }^{\circ} \mathrm{C}$ this percentage decreased.

The ferrotitaniferous sands suffer significant alterations from $900{ }^{\circ} \mathrm{C}$; therefore, the influence of the airflow, particle size and time was further analyzed at 900, 950 and $1,000{ }^{\circ} \mathrm{C}$. It was found that the airflow $(510 \mathrm{NL} / \mathrm{h})$ and smaller particle size $(75 \mu \mathrm{m})$ are not

Table 1 Chemical characterization.

\begin{tabular}{|c|c|c|c|c|c|c|c|c|}
\hline Element & $\mathrm{Fe}$ & $\mathrm{Ti}$ & $\mathrm{Si}$ & $\mathrm{Mg}$ & $\mathrm{Ca}$ & $\mathrm{Al}$ & $\mathrm{Na}$ & $\mathrm{Mn}$ \\
\hline Content (\%) & 52.1 & 15.4 & 2.0 & 1.0 & 0.9 & 0.5 & 0.2 & 0.2 \\
\hline
\end{tabular}




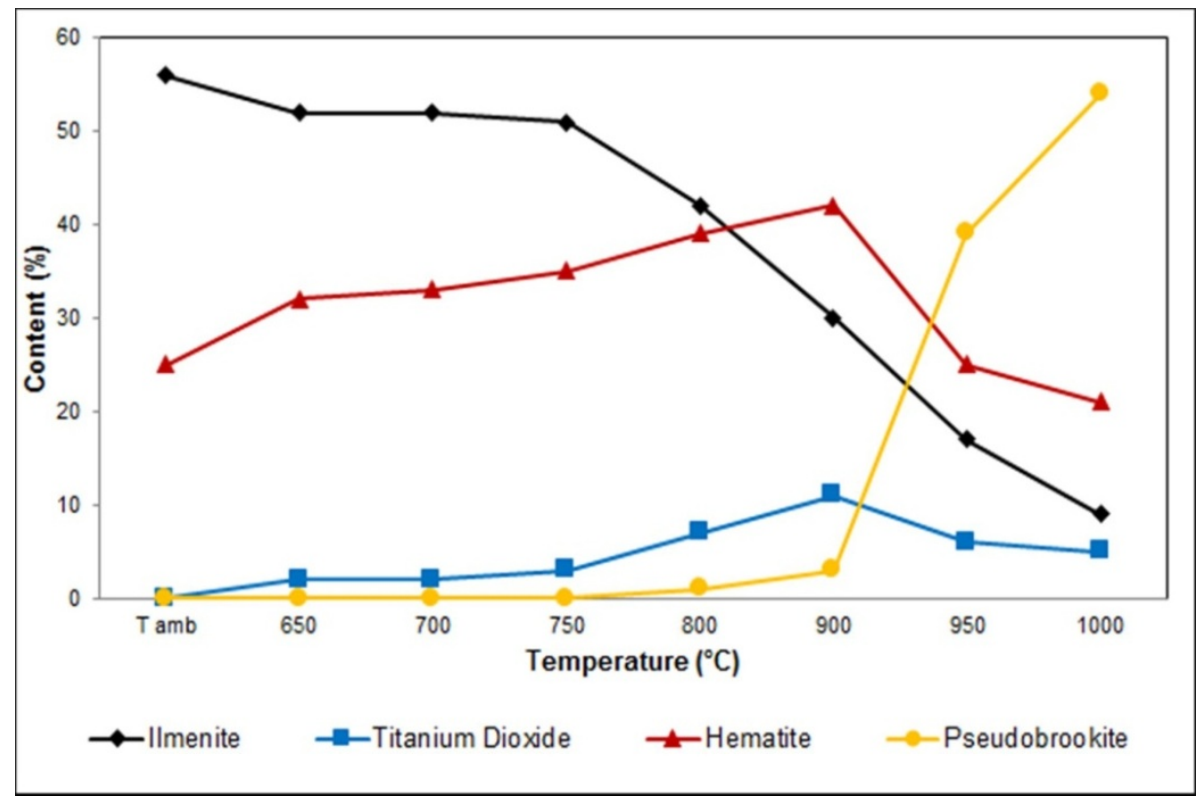

Fig. 1 Influence of temperature during the oxidation for $3 \mathrm{~h}$ with an airflow of $510 \mathrm{NL} / \mathrm{h}$.

Table 2 Contents of ilmenite and $\mathrm{TiO}_{2}$ obtained from samples oxidized without airflow and particle size of $177 \boldsymbol{\mu m}$.

\begin{tabular}{|c|c|c|c|c|c|c|c|c|c|}
\hline \multirow{2}{*}{$\begin{array}{l}\text { Temperature }\left({ }^{\circ} \mathrm{C}\right) \\
\text { Time }(\mathrm{h})\end{array}$} & \multicolumn{4}{|c|}{900} & \multicolumn{2}{|c|}{950} & \multicolumn{3}{|c|}{1,000} \\
\hline & 1 & 2 & 3 & 1 & 2 & 3 & 1 & 2 & 3 \\
\hline Ilmenite (wt\%) & 49 & 42 & 33 & 31 & 28 & 19 & 10 & 10 & 9 \\
\hline $\begin{array}{l}\text { Total } \mathrm{TiO}_{2}(\mathrm{wt} \%) \\
\text { (brookite + rutile) }\end{array}$ & 4 & 7 & 11 & 7 & 5 & 5 & 6 & 5 & 6 \\
\hline
\end{tabular}

significantly influential during oxidation, so the influence of time was evaluated without airflow and with the original particle size of $177 \mu \mathrm{m}$.

Table 2 shows the results obtained from the oxidative treatment.

The best oxidation conditions that showed the lowest content of ilmenite or the highest percentage of $\mathrm{TiO}_{2}$ were: no airflow at $900{ }^{\circ} \mathrm{C}$ for $3 \mathrm{~h}$ or no airflow at $1,000{ }^{\circ} \mathrm{C}$ for $1 \mathrm{~h}$. At $900{ }^{\circ} \mathrm{C}$ for $3 \mathrm{~h}$, a product with $33 \%$ of ilmenite and $11 \%$ of $\mathrm{TiO}_{2}$ was obtained, which resulted in $42 \%$ of conversion of ilmenite to $\mathrm{TiO}_{2}$, and at $1,000{ }^{\circ} \mathrm{C}$ for $1 \mathrm{~h}$ the product obtained consisted of $10 \%$ ilmenite and $6 \%$ of $\mathrm{TiO}_{2}$, which implied $23 \%$ of conversion to $\mathrm{TiO}_{2}$.

\subsection{Thermal Reductive Treatment}

The carbothermic reduction was performed at $1,050{ }^{\circ} \mathrm{C}$ for $1 \mathrm{~h}$ with $10,15,20$ and $40 \mathrm{wt} \%$ carbon to evaluate the influence of amount of carbon. These results are detailed in Fig. 2, which shows that as the percentage of carbon increased up to $20 \mathrm{wt} \%$, the titanomagnetite content increased. When the percentage of carbon increased to $40 \mathrm{wt} \%$, the contents of titanomagnetite and ilmenite remained constant.

The $10 \mathrm{wt} \%$ carbon was insufficient because the sample was oxidized to form $43 \%$ of pseudobrookite. With $15 \mathrm{wt} \%$ carbon, the sample was slightly oxidized forming $6 \%$ of pseudobrookite; however, residual carbon remained. Reduced samples with 20 and $40 \mathrm{wt} \%$ carbon showed similar mineralogical composition, and also a large amount of residual carbon. Therefore, $15 w t \%$ carbon was enough to prevent the sample oxidation, so this condition was constant during the study of the influence of gaseous atmosphere, temperature and reduction time.

The evaluation of the influence of temperature, gaseous atmosphere and reduction time are shown in Table 3.

The reductive condition that showed the highest decomposition of ilmenite and the highest content of 


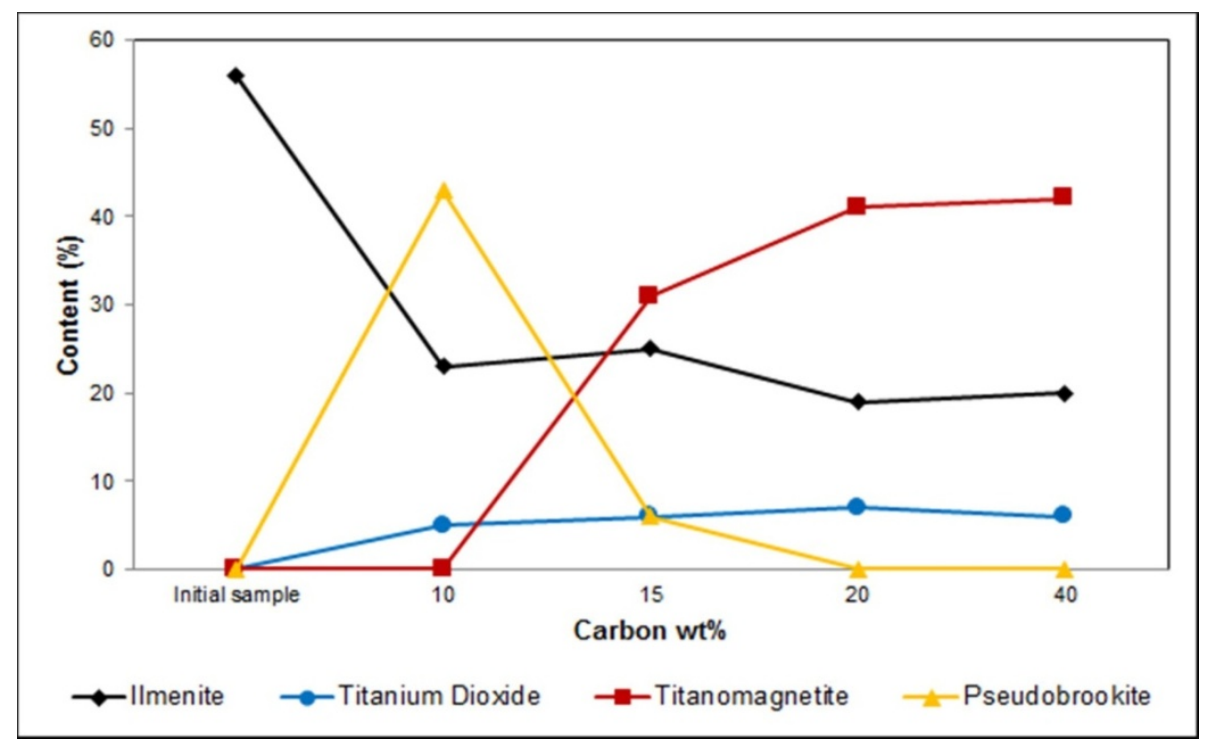

Fig. 2 Influence of the amount of carbon during the carbothermic reduction for $1 \mathrm{~h}$.

Table 3 Contents of ilmenite and $\mathrm{TiO}_{2}$ obtained from samples reduced with $15 \mathrm{wt} \%$ of carbon.

\begin{tabular}{lllll}
\hline Atmosphere & \multicolumn{3}{c}{ Without gaseous flow } & With $400 \mathrm{NL} / \mathrm{h}$ of $\mathrm{CO}_{2}$ \\
\hline Temperature $\left({ }^{\circ} \mathrm{C}\right)$ & 950 & 2 & 1,050 & 2 \\
Time (h) & 1 & 21 & 1 & 21 \\
Ilmenite (wt\%) & 32 & 6 & 18 & 5 \\
Total TiO $(\mathrm{wt} \%)$ & 4 & 5 & 5 \\
(brookite + rutile) & 4 & & 5 \\
\hline
\end{tabular}

Table 4 Contents of ilmenite and $\mathrm{TiO}_{2}$ obtained from oxidized-reduced samples.

\begin{tabular}{lll}
\hline Thermal treatment & $\begin{array}{l}\text { Oxidation at } 900^{\circ} \mathrm{C}(3 \mathrm{~h}) \\
\text { and reduction at } 9500^{\circ} \mathrm{C}(2 \mathrm{~h})\end{array}$ & $\begin{array}{l}\text { Oxidation at } 1,000{ }^{\circ} \mathrm{C}(1 \mathrm{~h}) \\
\text { and reduction at } 950{ }^{\circ} \mathrm{C}(2 \mathrm{~h})\end{array}$ \\
\hline Ilmenite $(\mathrm{wt} \%)$ & 9 & 18 \\
Total $\mathrm{TiO}_{2}(\mathrm{wt} \%)$ & 11 & 6 \\
\hline
\end{tabular}

$\mathrm{TiO}_{2}$ were $15 \mathrm{wt} \%$ of carbon at $950{ }^{\circ} \mathrm{C}$ for $2 \mathrm{~h}$ without gaseous flow.

\subsection{Thermal Oxidation-Reduction Treatment}

The oxidized samples that showed the lowest percentage of ilmenite or the highest percentage of $\mathrm{TiO}_{2}$ were selected and combined with the carbothermic reduction, in order to evaluate the influence of the combination of thermal treatments on the conversion of ilmenite to $\mathrm{TiO}_{2}$, since this combination enhances the efficiency of subsequent leaching process [7]. These results are shown in Table 4.

The content of ilmenite was higher in the pre-oxidized samples than in the only-reduced samples, and the $\mathrm{TiO}_{2}$ content did not exceed the percentage in the pre-oxidized samples at $900{ }^{\circ} \mathrm{C}$ for $3 \mathrm{~h}$. Therefore, the highest percentage of $\mathrm{TiO}_{2}$ was obtained with the sample oxidized at $900{ }^{\circ} \mathrm{C}$ and subsequently reduced at $950{ }^{\circ} \mathrm{C}$ for $2 \mathrm{~h}$ without gaseous flow.

\subsection{Titanium Dioxide Separation by Acid Leaching}

The $\mathrm{TiO}_{2}$ was separated from iron oxides and other impurities contained in the thermal treated ferrotitaniferous sands by leaching essays with $256 \mathrm{~g} / \mathrm{L}$ $\mathrm{HCl}$ at $70{ }^{\circ} \mathrm{C}$. The $\mathrm{TiO}_{2}$ was obtained as a solid cake after filtration. Essays were performed with $100 \mathrm{~mL}$ of $\mathrm{HCl}$ and $10 \%$ solids for $6 \mathrm{~h}$ with two different samples: a sample only reduced at $950{ }^{\circ} \mathrm{C}$ for $2 \mathrm{~h}$ and another oxidized at $900{ }^{\circ} \mathrm{C}$ for $3 \mathrm{~h}$ and then reduced at $950{ }^{\circ} \mathrm{C}$ 
for 2 h. The results of the acid leaching are shown in Fig. 3.

$\mathrm{TiO}_{2}$ recovery was calculated based on the initial mass of $\mathrm{TiO}_{2}$ found in the ilmenite and the amount of $\mathrm{TiO}_{2}$ obtained as final product. $\mathrm{TiO}_{2}$ recovery and purity percentages for only reduced sample were 19 and $78 \%$, respectively, while for oxidized-reduced sample, these percentages were 43 and 90\%, respectively.

Leaching essays were performed with $100 \mathrm{~mL}$ of $256 \mathrm{~g} / \mathrm{L} \mathrm{HCl}$ for $6 \mathrm{~h}$ at $70{ }^{\circ} \mathrm{C}$ with the sample oxidized at $900{ }^{\circ} \mathrm{C}$ for $3 \mathrm{~h}$ and then reduced at $950{ }^{\circ} \mathrm{C}$ for $2 \mathrm{~h}$ by varying the pulp density at 5, 10 and $20 \%$ solids. These results are shown in Fig. 4.

The recovery percentage of $\mathrm{TiO}_{2}$ with a pulp density of 5 and $10 \%$ solids was $43 \%$, while with $20 \%$ solids

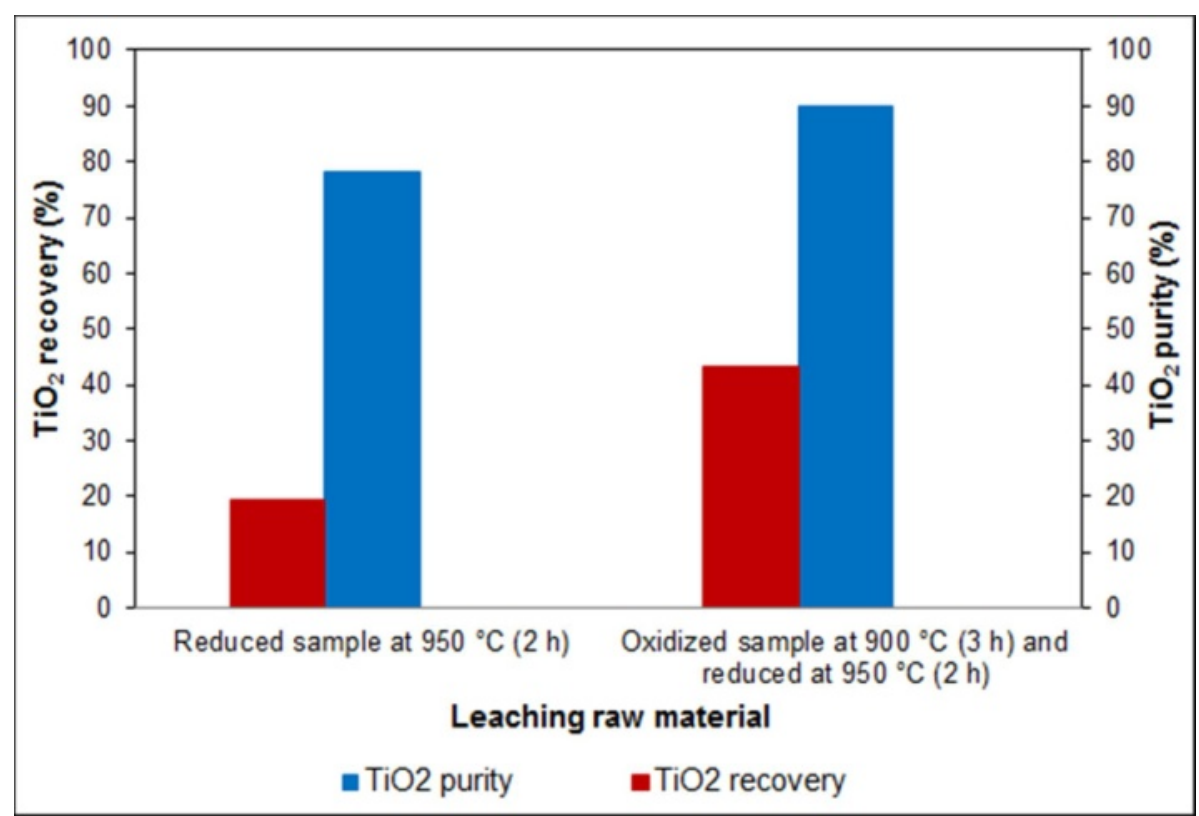

Fig. 3 Recovery and purity of $\mathrm{TiO}_{2}$ obtained from leaching essays of samples with different thermal treatments (10\% solids; $\mathrm{HCl}=256 \mathrm{~g} / \mathrm{L} ;$ time $=6 \mathrm{~h} ; \mathrm{T}=70^{\circ} \mathrm{C}$ ).

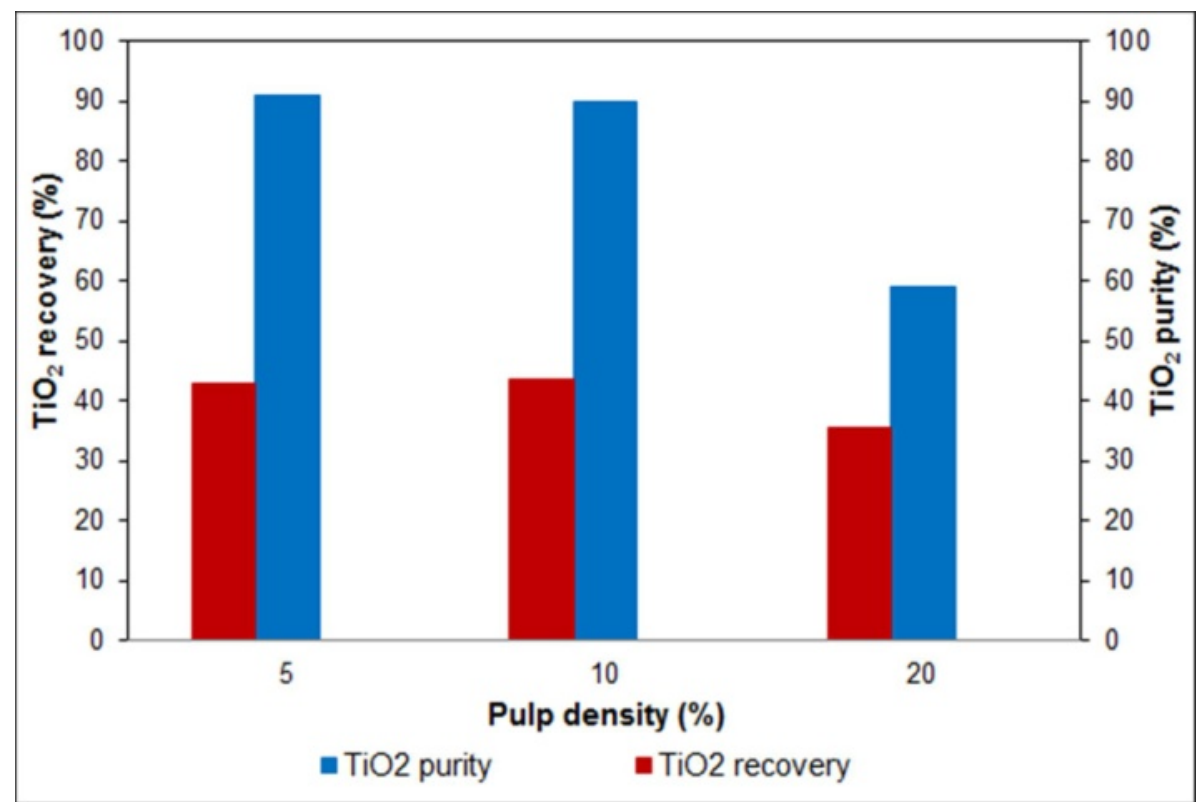

Fig. 4 Recovery and purity of $\mathrm{TiO}_{2}$ obtained from leaching essays with pulp densities of 5, 10 and $20 \%(\mathrm{HCl}=256 \mathrm{~g} / \mathrm{L}$; time = $\left.6 \mathrm{~h} ; \mathrm{T}=70^{\circ} \mathrm{C}\right)$. 


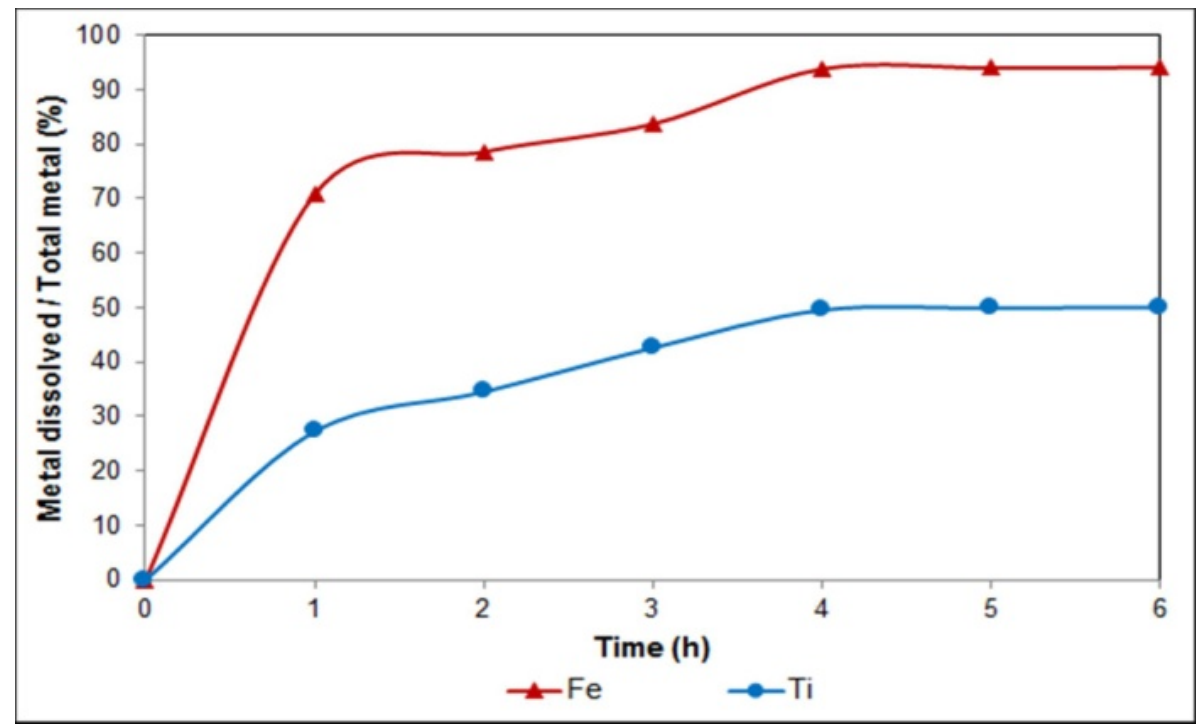

Fig. 5 Determination of the optimum leaching time with the dissolved Fe and Ti percentages (10\% solids; HCl = 256 g/L; time $=6 \mathrm{~h} ; \mathrm{T}=70^{\circ} \mathrm{C}$ ).

this percentage decreased to 35\%. At 5 and $10 \%$ solids, the purity of $\mathrm{TiO}_{2}$ was $90 \%$, while at $20 \%$, the purity decreased to $59 \%$. When the pulp density was $20 \%$, the $\mathrm{TiO}_{2}$ recovery and purity percentages decreased.

To establish the best pulp density for leaching, the product recovery percentage was evaluated. With pulp densities of 5, 10 and 20\%, the recoveries were 12, 13 and $16 \%$, respectively. Although the product recovery was higher at a pulp density of $20 \%$, the $\mathrm{TiO}_{2}$ purity was lower (59\%). Therefore, working at $10 \%$ solids was the best condition to achieve higher recovery, purity and production capacity.

Fig. 5 shows the results of dissolved $\mathrm{Ti}$ and dissolved $\mathrm{Fe}$ during acid leaching of the oxidized-reduced sample at different processing times.

At the first hour, $71 \%$ of $\mathrm{Fe}$ was dissolved, in the next two hours it increased to $84 \%$ and at the fourth hour, a plateau of $94 \%$ was reached. Dissolved $\mathrm{Ti}$ increased with time, and at the fourth hour, a plateau of $50 \%$ was attained. Therefore, a leaching time of $4 \mathrm{~h}$ was enough to reach the maximum removal of impurities.

\section{Discussion}

The density of the ferrotitaniferous sands is in according with the theoretical framework of the heavy minerals that compose these sands (ilmenite, hematite and magnetite).

The FRX analysis showed the presence of titanium and iron minerals. The $\mathrm{Ti}$ content of $15.4 \%$ corresponds stoichiometrically to $46 \%$ ilmenite or $26 \%$ of $\mathrm{TiO}_{2}$, which is the maximum amount of $\mathrm{TiO}_{2}$ that can be recovered from Mompiche sands. The FRX results also showed the sands have some impurities such as silicon ( $\mathrm{Si}$ ), magnesium (Mg), calcium (Ca), aluminum $(\mathrm{Al})$, sodium $(\mathrm{Na})$ and manganese $(\mathrm{Mn})$, which correspond to the cummingtonite. These ferrotitaniferous sands with 56\% ilmenite, as shown in the XRD analysis, cannot be considered as an ilmenite concentrate because a concentrate must be composed of more than $75 \%$ ilmenite $[15,16]$. Since the ilmenite content in these ferrotitaniferous sands is well below the minimum level required for industrial utilization, this work studied the leaching of oxidized-reduced ilmenite to improve the recovery process.

The behavior of the curves of Fig. 1 is almost consistent with Eqs. (3) and (4) because the stoichiometry of the reactions shows that with the first one, around $800{ }^{\circ} \mathrm{C}$, it obtains the double of $\mathrm{TiO}_{2}$ than with the second one, around $950{ }^{\circ} \mathrm{C}$. This is one reason why the content of $\mathrm{TiO}_{2}$ decrease at $950{ }^{\circ} \mathrm{C}$ and the pseudobrookite increase [10]. Hematite and $\mathrm{TiO}_{2}$ 
diminishing were in agreement with the previous research of Zhang and Ostrovski [17] who also found that at temperatures near to $1,000{ }^{\circ} \mathrm{C}$, these minerals react quickly to form pseudobrookite.

Comparing the oxidative results of this work with the results of Mozammel et al. [10], some differences were observed during oxidation, they reached the complete oxidation at $950^{\circ} \mathrm{C}$ for $2 \mathrm{~h}$, but in the present work even at $1,000{ }^{\circ} \mathrm{C}$ for $3 \mathrm{~h}$ the oxidation was incomplete. The reason of the larger oxidation percentages of Mozammel et al. [10] might be that they worked with ferrotitaniferous sands of 75.16\% ilmenite and a minor content of impurities. Another difference was that Mozammel et al. found a metastable intermediate phase $\left(\mathrm{Fe}_{2} \mathrm{O}_{3} \cdot 2 \mathrm{TiO}_{2}\right)$ which forms during heating of ilmenite at $700-1,000{ }^{\circ} \mathrm{C}$ [10], the metastable phase was not detected by the present study at the same temperatures.

The carbothermic reduction of ferrotitaniferous sands was partial since metallic iron and complete conversion of ilmenite to $\mathrm{TiO}_{2}$ were not obtained. Wang and Yuan [11] reported the formation of metallic iron during the carbothermic reduction with graphite (98\% fixed carbon) at $900{ }^{\circ} \mathrm{C}$ for $2 \mathrm{~h}$ of a Bama ilmenite concentrate $\left(49.78 \% \mathrm{TiO}_{2}\right)$, but they did not detect the titanomagnetite phase. The partial reduction of ferrotitaniferous sands was achieved, but a productive conversion of ilmenite to $\mathrm{TiO}_{2}$ was not obtained; however, more soluble minerals in $\mathrm{HCl}$ were obtaining, enhanced the subsequent leaching process.

The partial reduction obtained in the present work, even at $1,050{ }^{\circ} \mathrm{C}$ in $\mathrm{CO}_{2}$ for $2 \mathrm{~h}$, is not in agreement with the results found by Wang and Yuan [11], probably due to they used graphite that has more fixed carbon than the used in the present work or because of the higher content of impurities (including iron oxides, silicon, magnesium and manganese) and the lower content of ilmenite. Silicon, magnesium and manganese oxides inhibit the reduction of ilmenite and the iron oxides are reduced faster than ilmenite, which causes reduction competition between these minerals and making difficult the reduction process to obtain $\mathrm{TiO}_{2}[11,18]$.

The results on Table 4 show that it is better carried out the pre-oxidation at $900{ }^{\circ} \mathrm{C}$ than at $1,000{ }^{\circ} \mathrm{C}$, these are in agreement with Zhang and Ostrovski [17], who concluded that the pre-oxidation increases the reduction of iron oxides, but if sintering occurs (around $1,000{ }^{\circ} \mathrm{C}$ ), reduction is affected. However, Wang and Yuan [11] determined that performing the carbothermic reduction above $1,200{ }^{\circ} \mathrm{C}$ will enhance the ilmenite reduction because the effect of impurities and competition reactions becomes negligible.

Evidently, as shown in Fig. 3, applying the pre-oxidation at $900{ }^{\circ} \mathrm{C}$ for $3 \mathrm{~h}$ enhanced the leaching process by increasing the recovery and purity of $\mathrm{TiO}_{2}$, as Sarker et al. [7] also demonstrated. The diminishing on the recovery and purity of $\mathrm{TiO}_{2}$ in leaching process at $20 \%$ solids is probably due to the saturation of the solution; there is not enough $\mathrm{HCl}$ solution to dissolve all the iron oxides and other impurities. Additionally, when the solid percentage increases, there is less contact between the particles and the acid, diminishing the removal of Fe impurities, just as Van Dyk et al. [9] explained in their work.

\section{Conclusions}

Ferrotitaniferous sands from the north coast of Ecuador have a particle density of $4.9 \mathrm{~g} / \mathrm{cm}^{3}$, particle size of $177 \mu \mathrm{m}$, contents of Ti and Fe of 15.4 and 52.1\% respectively, and a mineralogical content of $56 \%$ ilmenite, $12 \%$ magnetite, $25 \%$ hematite and $7 \%$ cummingtonite.

The best oxidation conditions obtained were: $900{ }^{\circ} \mathrm{C}$ for $3 \mathrm{~h}$ reaching $42 \%$ conversion of ilmenite to $\mathrm{TiO}_{2}$, or oxidize at $1,000{ }^{\circ} \mathrm{C}$ for $1 \mathrm{~h}$ which was reached a conversion of $23 \%$.

The most favorable condition to perform the carbothermic reduction was $15 \mathrm{wt} \%$ carbon at $950{ }^{\circ} \mathrm{C}$ for $2 \mathrm{~h}$, which yields $21 \%$ ilmenite and $6 \% \mathrm{TiO}_{2}$.

Applying the oxidative-reductive treatment achieved the highest ilmenite decomposition and formation of 
$\mathrm{TiO}_{2}$. The oxidation yielded the highest conversion of ilmenite to $\mathrm{TiO}_{2}$, while the carbothermic reduction achieved the formation of titanomagnetite, which is a mineral more soluble in acids than ilmenite and completely soluble in $\mathrm{HCl}$.

The highest recovery and purity of $\mathrm{TiO}_{2}$ were 43 and $90 \%$ respectively, which were achieved by leaching a pulp of $10 \%$ solids with $100 \mathrm{~mL}$ of $256 \mathrm{~g} / \mathrm{L} \mathrm{HCl}$ at $70{ }^{\circ} \mathrm{C}$ for $4 \mathrm{~h}$, after an oxidation-reduction treatment. The $\mathrm{TiO}_{2}$ obtained of $90 \%$ purity corresponds, $87 \%$ to rutile phase and 3\% to brookite phase.

The advantage of the $\mathrm{HCl}$ leaching was that we could obtain a $\mathrm{TiO}_{2}$ with high purity in a few hours with a less amount of reactants, but the disadvantage was that almost a half of $\mathrm{TiO}_{2}$ was lost in the leaching solution. However, it could increase the study to determine another process to recover the $\mathrm{TiO}_{2}$ from leaching solution and probably with a higher purity.

Another way to improve the process could be to implement a method of ilmenite concentration before thermal treatments or increase the carbothermic reduction temperature above $1,200{ }^{\circ} \mathrm{C}$ in order to enhance the reduction process.

\section{References}

[1] Díaz, J. 2013. “Caracterización Geológica y Geofísica de la Zona Oeste de la Concesión Minera Mompiche, Ubicada en la Provincia de Esmeraldas, Cantón Muisne, Recinto Mompiche." Engineering thesis, Escuela Politécnica Nacional.

[2] Chuquirima, G., and Cortez, L. 2014. "Estudio y Obtención de Metal de Hierro a Partir de Arenas Ferruginosas.” Engineering thesis, Escuela Politécnica Nacional.

[3] Empresa Nacional Minera. 2012. “Tola Norte Muestra Potencial de Hierro Para Beneficio del País y Las Comunidades.” Accessed March 21, 2015, http://www.enamiep.gob.ec/es/Boletines/tola-norte-muest ra-potencial-de-hierro-para-beneficio-del-pais-y-las-comu nidades.html.

[4] Filippou, D., and Hudon, G. 2009. "Iron Removal and Recovery in the Titanium Dioxide Feedstock and Pigment Industries.” Overview 61 (10): 36-42.

[5] Yuan, Z., Wang, X., Xu, C., Li, W., and Kwauk, M. 2006.
"A New Process for Comprehensive Utilization of Complex Titania Ore.” Minerals Engineering 19: 975-8.

[6] Middlemas, S., Fang, Z., and Fan, P. 2013. "A New Method for Production of Titanium Dioxide Pigment.” Hydrometallurgy 131-132: 107-13.

[7] Sarker, M., Rashid, A., and Kurny, A. 2006. "Kinetics of Leaching of Oxidized and Reduced Ilmenite in Dilute Hydrochloric Acid Solutions.” International Journal of Mineral Processing 80: 223-8.

[8] Liang, B., Li, C., Zhang, C., and Zhang, Y. 2005. "Leaching Kinetics of Panzhihua Ilmenite in Sulfuric Acid.” Hydrometallurgy 76: 173-9.

[9] Van Dyk, J., Vegter, N., and Pistorius, P. 2002. "Kinetics of Ilmenite Dissolution in Hydrochloric Acid." Hydrometallurgy 65: 31-6.

[10] Mozammel, M., Sadrnezhaad, S. K., Khoshnevisan, A., and Youzbashizadheh, H. 2013. "Kinetics and Reaction Mechanism of Isothermal Oxidation of Iranian Ilmenite Concentrate Powder." Journal of Thermal Analysis and Calorimetry 112 (2): 781-9.

[11] Wang, Y., and Yuan, Z. 2006. "Reductive Kinetics of the Reaction between a Natural Ilmenite and Carbon.” International Journal of Mineral Processing 81: 133-40.

[12] Chen, Y., Hwang, T., Marsh, M., and Williams, J. S. 1997. "Mechanically Activated Carbothermic Reduction of Ilmenite.” Metallurgical and Materials Transactions A 28 (5): 1115-21.

[13] Banco Central del Ecuador. 2002. "Consulta de totales por nandina”. Accessed February 18, 2016. http://www.bce.fin.ec/comercioExterior/comercio/consult aTotXNandinaPaisConGrafico.jsp.

[14] Klein, C., and Hurlbut, C. S. 1999. "Manual of Mineralogy.” In Systematic Mineralogy, XI. New York, United States: John Wiley \& Sons.

[15] Valderrama, L., Poblete, R., and Contretas, C. 2005. “Caracterización y Concentración de Muestras de Arenas de Caldera, Región de Atacama.” Revista de la Facultad de Ingeniería 19: 38-44.

[16] Xiong, X., Zhi, Y., and Hongyong, O. 2011. "Study on Character of Ilmenite Modified by Thermal Treatment." Advanced Materials Research 284-6: 2090-3.

[17] Zhang, G., and Ostrovski, O. 2002. "Effect of Preoxidation and Sintering on Properties of Ilmenite Concentrates.” International Journal of Mineral Processing 64: 201-18.

[18] Si, X., Lu, X., Li, C., Li, C., and Ding, W. 2012. "Phase Transformation and Reduction Kinetics during the Hydrogen Reduction of Ilmenite Concentrate.” International Journal of Minerals, Metallurgy and Materials 19 (5): 384-90. 